\title{
Management of Hypertension in the Elderly Patients: A Systematic Review
}

\section{Zakiah Dianah ${ }^{1}$ and Vidhia Umami}

1Postgraduate Student, Faculty of Public Health University of Indonesia, Depok, Indonesia

${ }^{2}$ Medical Staff, Division of Nephrology and Hypertension, Department of Internal Medicine Faculty of Medicine University of Indonesia - Cipto Mangunkusumo General Hospital, Jakarta, Indonesia

\section{Abstract}

Hypertension is one of the most common disease but it has adverse effects on target organs such as heart, brain, kidneys, and blood vessels if not treated properly. The management of hypertension could be different in some special population, such as in the elderly. In this population, there are special things to be considered, such as antihypertension drugs choices and blood pressure target. The purpose of this article was to provide information about the current management of hypertension in the elderly. The method used was systematic review with PRISMA protocol. Journal review

Corresponding Author:

Zakiah Dianah

dianah.zakiah@gmail.com

Vidhia Umami

vidhiaumami@yahoo.com

Received: 21 December 2018

Accepted: 23 January 2019

Published: 28 February 2019

Publishing services provided by Knowledge E

(c) Zakiah Dianah and Vidhia Umami. This article is distributed under the terms of the

Commons Attribution License, which permits unrestricted use and redistribution provided that the original author and source are credited.

Selection and Peer-review under the responsibility of the $3 \mathrm{rd}$ IMOPH \& the 1st YSSOPH Conference Committee.

\section{G OPEN ACCESS} results concluded that antihypertensive drugs therapy in elderly starts at blood pressure $>140 / 90 \mathrm{mmHg}(130 / 85 \mathrm{mmHg}$ if there is complication of diabetes, kidney disease, and cardiovascular); optimum target of systolic blood pressure is $120-140 \mathrm{mmHg}$ and diastolic blood pressure not less than $65 \mathrm{mmHg}$; antihypertension drugs choices base on comorbidities and patient response to medication; and lifestyle modification is necessary to reduce cardiovascular risk and reduce the amount of drug consumed.

Keywords: hypertension, elderly, management

\section{Introduction}

Epidemiological transition leads to change disease patterns from communicable diseases to non-communicable diseases [1]. The occurrence of this epidemiological transition is due to changes in socioeconomic, environmental, and population structure. People have adopted an unhealthy lifestyle, such as smoking, lack of physical activity, and high-fat/alcohol consumption. The unhealthy lifestyle is thought to be a risk factor for non-communicable diseases. The World Health Organization estimates that by 2020 non-infectious diseases will account for $73 \%$ of deaths and $60 \%$ of all morbidity in the world. It is estimated that the most affected countries are developing countries, including Indonesia [2].

Hypertension is one of the non-communicable diseases that are common in everyday clinical practice. Data of Riset Kesehatan Dasar 2013 shows that the prevalence of hypertension in Indonesia is 25.8\% [3]. Hypertension has effects on many target organs such as the heart, brain, kidney, and blood vessels [4]. 
Early detection, such as regular blood pressure measurement and appropriate management, can reduce complication risk. Hypertension can attack all ages, but older people are more common to have the disease. Hypertension in the elderly requires special treatment because there is an interaction between hypertension and cardiovascular risk factors [5, 6]. This is confirmed by results of Hypertension in the Very Elderly Trial (HYVET) and The Systolic Blood Pressure Intervention Trial (SPRINT) study which state that management of hypertension in elderly patients needs to be distinguished from adult patients to reduce morbidity and mortality [7-9]. This paper compares some articles from international journals which explain about the treatment of hypertension in elderly.

Hypertension in elderly needs to be discussed because it often finds cases of mild hypertension in elderly that does not get any treatment. Besides, the blood pressure target that has to be achieved sometimes confuses the clinicians. Hopefully, this paper can provide detail information about the management of hypertension in the elderly.

This article was created to discuss some articles of international journals on the treatment of hypertension in the elderly. The authors feel the need to discuss this because during this understanding of the community often find it common when found high blood pressure in the elderly, so no treatment is done. Target blood pressure to be achieved even sometimes confuse the clinicians. It is hoped that this paper can provide new and detailed information about the management of hypertension in the elderly, both medical and non-medical procedures.

\section{Methods}

This paper used systematic review based on the Preferred Reporting Items for Systematic Review and Meta Analyzes Statement (PRISMA) 2009 (10).

\subsection{Search strategy (Literature search and literature selection)}

Literatures are searched by using electronic databases such as Springer Link, Proquest, and Google Scholar with the keyword "hypertension in elderly patients" and using published journals from 2010 to 2016. Inclusion criteria are all articles from various countries about hypertension in elderly, in English, has a citation, and published in 2010-2016 while the exclusion criteria are articles that are not relevant to the topic of hypertension in the elderly.From 3 electronic databases f,from 2010 to 2016, researchers obtained 991 journal articles consisting of 40 articles from Springer Link, 141 articles from ProQuest, and 810 articles from Google Scholar. Firstly, the articles were filtered by keyword, then title, inclusion and exclusion criteria and finally researchers assess the full article. There were seven articles relevant to the topic consisting of research articles, meta-analysis and systematic review (Figure 1). 
Searching in database by keyword $(\mathrm{n}=991)$

- Proquest $(n=141)$

- Spinger Link $(\mathrm{n}=40)$

- Google scholar $(\mathrm{n}=810)$

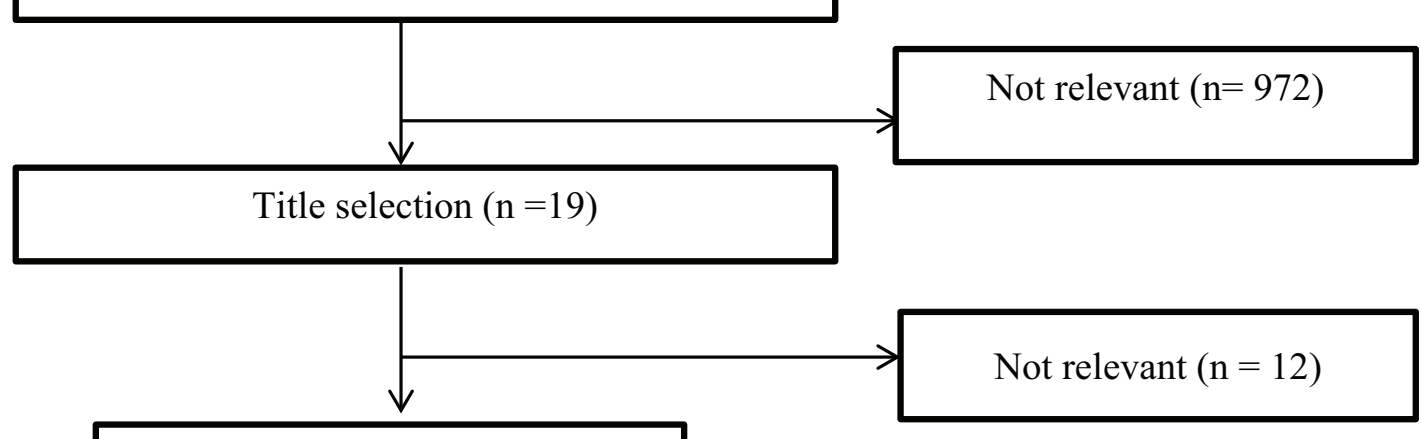

Article $(\mathrm{n}=7)$

Figure 1: The process/diagram for searching the articles.

\section{Results}

TABLE 1: Summary of the article included in the systematic review.

\begin{tabular}{|c|c|c|c|}
\hline Title & Author & Source & Results \\
\hline $\begin{array}{l}\text { Optimal } \\
\text { management } \\
\text { of } \\
\text { hypertension } \\
\text { in elderly } \\
\text { patients }\end{array}$ & $\begin{array}{l}\text { Maria C. } \\
\text { Acelajado }\end{array}$ & $\begin{array}{l}\text { Integrated } \\
\text { Blood } \\
\text { Pressure } \\
\text { Control } 10 \\
\text { November } \\
2010\end{array}$ & $\begin{array}{l}\text { Antihypertension therapy starts at blood pressure }> \\
140 / 90 \mathrm{mmHg}(130 / 85 \mathrm{mmHg} \text { when there are } \\
\text { complications of diabetes, kidney disease and } \\
\text { cardiovascular). } \\
\text { - Lifestyle modification needs to be done such as } \\
\text { increasing physical activity, low-sodium diet, reducing } \\
\text { weight / maintaining ideal body weight and reducing } \\
\text { alcohol consumption. } \\
\text { - The degree of decreased blood pressure is more } \\
\text { important than the selection of antihypertension drugs. } \\
\text { - Combination therapy is the renin-angiotensin system } \\
\text { blocker with diuretics or with calcium channel blockers. } \\
\text { - The management of hypertension in elderly is } \\
\text { influenced by many factors such as the tendency for } \\
\text { orthostatic hypotension, polypharmacy, and incidence } \\
\text { of cognitive impairment. }\end{array}$ \\
\hline
\end{tabular}




\begin{tabular}{|c|c|c|c|}
\hline Title & Author & Source & Results \\
\hline $\begin{array}{l}\text { Hypertension } \\
\text { in elderly: } \\
\text { What Is the } \\
\text { Goal Blood } \\
\text { Pressure } \\
\text { Target and } \\
\text { How This } \\
\text { Can Be } \\
\text { Attained? }\end{array}$ & $\begin{array}{l}\text { Bo Carlberg, } \\
\text { Peter M. } \\
\text { Nilsson }\end{array}$ & $\begin{array}{l}\text { Curr } \\
\text { Hypertens } \\
\text { Rep (2010) 12: } \\
331-334\end{array}$ & $\begin{array}{l}\text { Selection of anti-hypertension drugs is not based on } \\
\text { the age of patients because the drugs have the same } \\
\text { effect between elderly patients and adult patients. } \\
\text { - Antihypertension drugs begin to be given when } \\
\text { systolic blood pressure (SBP) }>140 \mathrm{mmHg} \text {, the target } \\
\text { of SBP is }<140 \mathrm{mmHg} \text {. } \\
\text { - Be aware of drug side effects. } \\
\text { - There is an advantage when giving anti-hypertension } \\
\text { drugs to healthy elderly people aged }>80 \text { years, but } \\
\text { be careful of existing comorbidities, such as dementia. } \\
\text { - Drug combination such as Angiotensin Converting } \\
\text { Enzyme (ACE) inhibitor with diuretic or calcium } \\
\text { antagonist. Beta-receptor blockers are given when } \\
\text { there is ischemic heart disease. }\end{array}$ \\
\hline $\begin{array}{l}\text { New AHA } \\
\text { guidelines } \\
\text { help manage } \\
\text { hypertension } \\
\text { in the elderly }\end{array}$ & $\begin{array}{l}\text { Anna D. } \\
\text { Garrett, } \\
\text { PharmD, } \\
\text { BCPS }\end{array}$ & $\begin{array}{l}\text { Drug Topics } \\
\text { April } 2012\end{array}$ & $\begin{array}{l}\text { If SBP }<150 \mathrm{mmHg} \text { has been achieved with } 1 \text { or } 2 \\
\text { antihypertension drugs, then it can be considered to } \\
\text { lower SBP }<140 \mathrm{mmHg} \text {. If the patient ages } \geq 80 \text { years, } \\
\text { SBP } 140-145 \mathrm{mmHg} \text { is acceptable. SBP } \geq 150 \mathrm{mmHg} \text { is } \\
\text { still acceptable if a combination of } 4 \text { types of target } \\
\text { antihypertensive drugs is still unreachable; there are } \\
\text { unwanted side effects, and diastolic blood pressure } \\
\text { (DBP) drops to } \leq 65 \mathrm{mmHg} \text {. } \\
\text { - Lifestyle modification. } \\
\text { - Recommended antihypertension drugs are ACE } \\
\text { inhibitor group, angiotensin receptor blocker (ARB), } \\
\text { calcium channel blocker, a beta-blocker, or diuretic. } \\
\text { Beta-blockers can not be used as first-line therapy } \\
\text { when there is no indication. } \\
\text { - Be aware of the risk of orthostatic hypotension } \\
\text { especially in patients with isolated systolic } \\
\text { hypertension (ISH). }\end{array}$ \\
\hline $\begin{array}{l}\text { Management } \\
\text { of } \\
\text { Hypertension } \\
\text { in the Elderly } \\
\text { Population }\end{array}$ & $\begin{array}{l}\text { Raymond V. } \\
\text { Oliva, George } \\
\text { L. Bakris }\end{array}$ & $\begin{array}{l}\text { Journal of } \\
\text { Gerontology: } \\
\text { Medical } \\
\text { Sciences } \\
2012\end{array}$ & $\begin{array}{l}\text { Lifestyle modification can be done in patients with mild } \\
\text { hypertension, such as stop smoking, lose weight, } \\
\text { reduce stress, salt, and alcohol, as well as increase } \\
\text { physical activity. It can lower the doses of drugs taken. } \\
\text { - Selection of anti-hypertension drugs depends on the } \\
\text { patient's condition. Use of diuretics is not } \\
\text { recommended for patients with electrolyte disorders, } \\
\text { calcium antagonists may be administered to patients } \\
\text { with arterial dysfunction, but should be avoided by } \\
\text { patients with left ventricular dysfunction. For patients } \\
\text { with diabetes can be given ACE inhibitors. } \\
\text { - Compared with diuretics, ACE inhibitors have a better } \\
\text { effect on cardiovascular and reduce the risk of kidney } \\
\text { disease. } \\
\text { - Intake of water needs to be considered because } \\
\text { elderly patients tend to drink less, to avoid electrolyte } \\
\text { disturbance. }\end{array}$ \\
\hline $\begin{array}{l}\text { Blood } \\
\text { pressure } \\
\text { control in the } \\
\text { Hypertension } \\
\text { in the Very } \\
\text { Elderly Trial } \\
\text { (HYVET) }\end{array}$ & $\begin{array}{l}\text { CJ Bulpitt, } \\
\text { NS Beckett, R } \\
\text { Peters, G } \\
\text { Leonetti, V } \\
\text { Gergova, R } \\
\text { Fagard, LA } \\
\text { Burch, W } \\
\text { Banya, AE } \\
\text { Fletcher }\end{array}$ & $\begin{array}{l}\text { Journal of } \\
\text { Human } \\
\text { Hypertension } \\
2012\end{array}$ & $\begin{array}{l}\text { Combination of indapamide SR } 1.5 \mathrm{mg} \pm \text { perindopril } 2-4 \\
\mathrm{mg} \text { decreased SBP by } 17 \mathrm{mmHg} \text { and DBP } 7 \mathrm{mmHg} \\
\text { compared with placebo in systolic and diastolic } \\
\text { hypertensive patients. In ISH patients, the effects of } \\
\text { both drugs decreased SBP } 19.3 \mathrm{mmHg} \text { and DBP } 2 \\
\mathrm{mmHg} \text {. } \\
\text { - The risk of stroke is reduced by } 30 \% \text { by reducing SBP. }\end{array}$ \\
\hline
\end{tabular}




\begin{tabular}{|c|c|c|c|}
\hline Title & Author & Source & Results \\
\hline $\begin{array}{l}2014 \\
\text { Evidence- } \\
\text { Based } \\
\text { Guideline for } \\
\text { Management } \\
\text { of High Blood } \\
\text { Pressure in } \\
\text { Adults Report } \\
\text { from the } \\
\text { Panel } \\
\text { Members } \\
\text { Appointed to } \\
\text { the Eight } \\
\text { Joint National } \\
\text { Committee } \\
\text { (JNC8) }\end{array}$ & $\begin{array}{l}\text { Paul A. } \\
\text { James, MD; } \\
\text { Suzanne } \\
\text { Oparil, MD; } \\
\text { Barry L. } \\
\text { Carter, } \\
\text { PharmD, et al } \\
\end{array}$ & $\begin{array}{l}\text { JAMA } \\
\text { February 5, } \\
2014 \text { Volume } \\
311, \text { Number } \\
5\end{array}$ & $\begin{array}{l}\text { Lowering blood pressure up to } 150 / 90 \text { is still } \\
\text { acceptable. } \\
\text { - Lifestyle modifications such as healthy diet, weight } \\
\text { control, and regular physical exercise, are } \\
\text { recommended because it can lower blood pressure } \\
\text { and reduce the amount of drug consumed. }\end{array}$ \\
\hline $\begin{array}{l}\text { Intensive vs. } \\
\text { Standart } \\
\text { Blood } \\
\text { Pressure } \\
\text { Control and } \\
\text { Cardiovascu- } \\
\text { lar Disease } \\
\text { Outcomes in } \\
\text { Adults Aged } \\
\geq 75 \text { years A } \\
\text { Randomized } \\
\text { Clinical Trial }\end{array}$ & $\begin{array}{l}\text { Jeff D. } \\
\text { Williamson, } \\
\text { MD, MHS; } \\
\text { Mark A. } \\
\text { Supiano, MD; } \\
\text { William B. } \\
\text { Applegate, } \\
\text { MD, MPH }\end{array}$ & $\begin{array}{l}\text { JAMA. } \\
2016 ; 315(24): 2 \\
2682\end{array}$ & $\begin{array}{l}\text { In patients over the age of } 75 \text {, reducing a patient's } \\
\text { blood pressure to } 120 \mathrm{mmHg} \text { compared to } 140 \mathrm{mmHg} \\
\text { has a significant effect on fatal cardiovascular events } \\
\text { and other causes of death. }\end{array}$ \\
\hline
\end{tabular}

\section{Discussion}

Management of hypertension in the elderly is same as a management in an adult patient, which is preceded by a non-medical therapy that is lifestyle modification, combined with the management of antihypertension drug therapy $[7,8,11,12]$. Hypertensive patients are encouraged to reduce salt/sodium and alcohol consumption [7, 12]. Smoking as a risk factor for cardiovascular disease also needs to be stopped. Patients also need to reduce stress because it can also trigger a rise in blood pressure [12]. Other examples of lifestyle modification are weight loss and regular physical activity [7, 8, 12]. Non-medical therapy can reduce the consumption of anti-hypertension drugs [8]. Anti-hypertension drugs are given according to each patient's condition and are not age-based $[6,12]$. Treatments that can be given are drugs from the class of ACE inhibitors, angiotensin receptor blockers (ARBs), calcium channel blockers, beta-blockers, and diuretics [11]. The use of diuretics is not recommended for patients with electrolyte disorders, calcium antagonists may be administered to patients with arterial dysfunction, but should be avoided by patients with left ventricular dysfunction. For patients with diabetes can be given ACE inhibitors [11]. Compared with diuretics, ACE inhibitors have a better cardiovascular effect and reduce the risk of kidney disease [12]. From the results of HYVET research, the combination of an anti-hypertension drug indapamide SR $1.5 \mathrm{mg} \pm$ perindopril 2-4 mg reduced SBP by $17 \mathrm{mmHg}$ and DBP $7 \mathrm{mmHg}$ compared with placebo in systolic and diastolic hypertensive patients. In ISH patients, the effects of both drugs decreased SBP $19.3 \mathrm{mmHg}$ and DBP $2 \mathrm{mmHg}$ [13]. 
From the journals above, there are differences regarding blood pressure that begins to be treated with medication and blood pressure target to be achieved. There are statements to start anti-hypertension drug therapy at blood pressure $>140 / 90 \mathrm{mmHg}$ or $130 / 85 \mathrm{mmHg}$ when there are complications of diabetes, kidney disease, and cardiovascular [7]. Meanwhile, the others only pay attention to SBP $>140 \mathrm{mmHg}$ [6]. Systolic blood pressure reduction target also varies, which is $<140 \mathrm{mmHg}$ and up to $120 \mathrm{mmHg}[6,14]$. Systolic blood pressure $\geq 150 \mathrm{mmHg}$ is still acceptable in conditions in which patients already get a combination of 4 types of anti-hypertension drugs; there are unwanted drug side effects, and DBP decreases to $\leq 65 \mathrm{mmHg}$ [11]. Things to consider when administering anti-hypertension drugs are side effects such as orthostatic hypotension [7, 11]. Polypharmacy also often occurs because elderly patients usually consume drugs for other diseases therapy [7]. Water intake should be monitored to avoid electrolyte disturbance [12].

\section{Conclusion}

Treatment of anti-hypertension drugs in elderly starts at blood pressure $>140 / 90 \mathrm{mmHg}$ (130/85 $\mathrm{mmHg}$ if there is a complication of diabetes, kidney disease, and cardiovascular). The optimum target of systolic blood pressure is $120-140 \mathrm{mmHg}$ and diastolic blood pressure is not less than $65 \mathrm{mmHg}$. Anti-hypertension drugs are adjusted to comorbidities and patient response. Lifestyle modification is needed to reduce cardiovascular risk and reduce the amount of drug consumed.

\section{Conflict of Interest}

Authors declare that there is no conflict of interest.

\section{References}

[1] Gordis L. Epidemiology. Fourth Edi. Epidemiology. Philadelphia: Joan Sinclair; 2008. p. 247-265 hal.

[2] Rahajeng E, Tuminah S. Prevalensi Hipertensi dan Determinannya di Indonesia. Maj Kedokt Indonesia. 2009;59(12):580-7.

[3] Health M of. Riset Kesehatan Dasar [Internet]. Jakarta: MoH; 2013. 1-200 hal. Available at: http://labdata. litbang.depkes.go.id/riset-badan-litbangkes/menu-riskesnas/menu-riskesdas/374-rkd-2013

[4] Bandiara R. An Update Management Concept in Hypertension. In Bandung; 2008. hal. 8.

[5] Aronow WS, Fleg JL, Pepine CJ, Artinian NT, Bakris G, Brown AS, et al. ACCF/AHA 2011 Expert Consensus Document on Hypertension in the Elderly. J Am Soc Hypertens [Internet]. 2011;5(4):259352. Available at: http://linkinghub.elsevier.com/retrieve/pii/S1933171111001549

[6] Carlberg B, Nilsson PM. Hypertension in the elderly: What is the Goal Blood Pressure Target and How Can this be Attained? Curr Hypertens Rep. 2010;12(5):331-4.

[7] Acelajado MC. Optimal management of hypertension in elderly patients. Integr Blood Press Control [Internet]. 2010;3:145-53. Available at: http://www.pubmedcentral.nih.gov/articlerender.fcgi?artid= 3172073\&tool=pmcentrez\&rendertype=abstract

[8] James PA, Oparil S, Carter BL, Cushman WC, Dennison-Himmelfarb C, Handler J, et al. 2014 EvidenceBased Guideline for the Management of High Blood Pressure in Adults. Jama [Internet]. 2014;311(5):507. Available at: http://jama.jamanetwork.com/article.aspx?doi=10.1001/jama.2013.284427

[9] Blok CGH, de Ridder M a. J, Verhamme KMC, Moorman PW. Hypertension in Older Patients, A Retrospective Cohort Study. BMC Geriatr [Internet]. 2016;16(1):142. Available at: http://bmcgeriatr. biomedcentral.com/articles/10.1186/s12877-016-0316-0 
[10] Moher D. Systematic Reviews and Meta-Analyses: The PRISMA Statement. Annuals of Internal Medicine. 2009;151(4):264-9. Available at: papers2://publication/uuid/8E18828D-1880-40C4-A4CCBD7821A2E97E

[11] Garrett AD. New AHA Guidelines Help Manage Hypertension in The Elderly. Drug Topics. 2012;156(4).

[12] Oliva R V., Bakris GL. Management of Hypertension in the Elderly Population. Journals Gerontol Ser A Biol Sci Med Sci [Internet]. 2012;67(12):1343-51. Available at: https://academic.oup.com/ biomedgerontology/article-lookup/doi/10.1093/gerona/gls148

[13] Bulpitt CJ, Beckett NS, Peters R, Leonetti G, Gergova V, Fagard R, et al. Blood pressure control in the Hypertension in the Very Elderly Trial (HYVET). J Hum Hypertens [Internet]. 2012;26(3):157-63. Available at: http://www.nature.com/doifinder/10.1038/jhh.2011.10

[14] Williamson JD, Supiano MA, Applegate WB, Berlowitz DR, Campbell RC, Chertow GM, et al. Intensive vs. Standard Blood Pressure Control and Cardiovascular Disease Outcomes in Adults Aged $\geq 75$ Years. Jama [Internet]. 2016;315(24):2673. Available at: http://jama.jamanetwork.com/article.aspx?doi=10.1001/ jama.2016.7050 